\title{
Physico-Chemical and Labeling Control of Imported Honeys in Burkina Faso
}

\author{
Schweitzer Paul ${ }^{1}$, Nombré Issa ${ }^{2,3}$, Aidoo Kwamé ${ }^{4}$, Boussim I. Joseph ${ }^{3}$ \\ ${ }^{1}$ Laboratoire d'Analyses et d'Ecologie Apicole Centre d'Etudes Techniques Apicole de Moselle, Guenange, France; ${ }^{2}$ Institut des \\ Sciences, Ouagadougou, Burkina Faso; ${ }^{3}$ Laboratoire de Biologie et Écologie Végétales UFR Science et Technique Université de \\ Ouagadougou, Ouagadougou, Burkina Faso; ${ }^{4}$ International Stingless Bee Centre, Department of Entomology and Wildlife, Univer- \\ sity of Cape Coast, Cape Coast, Ghana. \\ Email: nombre_issa@yahoo.fr
}

Received September $4^{\text {th }}, 2013$; revised October $4^{\text {th }}, 2013$; accepted October $11^{\text {th }}, 2013$

Copyright (C) 2013 Schweitzer Paul et al. This is an open access article distributed under the Creative Commons Attribution License, which permits unrestricted use, distribution, and reproduction in any medium, provided the original work is properly cited. In accordance of the Creative Commons Attribution License all Copyrights (C) 2013 are reserved for SCIRP and the owner of the intellectual property Schweitzer Paul et al. All Copyright (C) 2013 are guarded by law and by SCIRP as a guardian.

\begin{abstract}
Burkina Faso is situated in the centre of Western Africa with a high illiteracy rate, despite efforts of the governments to improve education. This is not without consequences on the choice of foodstuffs bought and consumed by the people and the consequent effect on their health. Honey is one of the foodstuffs consumed by people. However local production falls short of demand, and so most supermarkets in Burkina Faso sell imported honey. Do these imported honeys conform to the international standards regarding labeling of foodstuffs, and specifically do they possess physicochemical characteristics that conform to international norms of Codex Alimentarus and European honey Commission? The study investigated certain characteristics established by standards of the European Commission and Codex Alimentarius. The labels on packaged honey were analyzed according to the standard of Journal Officiel. Results show that the physic-chemical plan, the hydroxyl-methyl-furfural (HMF) content were high whereas the diastase index was low indicating lack of freshness of imported honeys. For the stability, honey samples conformed to the standard of the European Commission and Codex Alimentarius. Only two honey samples fulfill the Codex Alimentarius and the European commission norms. Storage temperatures degrade honey considerably and it suggested that under tropical conditions the deadline for optimal use (DLUO) of honeys is reduced to one year.
\end{abstract}

Keywords: Honey Analysis; Food Labeling; Consumption Deadline; Burkina Faso

\section{Introduction}

Honey is defined as the natural sweet substance, produced by honeybees from the nectar of plants or from secretions of living parts of plants, or excretions of plant-sucking insects on the living parts of plants, which the bees collect, transform by combining with specific substances of their own, deposit, dehydrate, store and leave in honeycombs to ripen and mature [1-3]. So, all honeys intended for human consumption must conform to this definition. Unfortunately, honeys that do not conform to these criteria are found on sale in super markets of Burkina Faso. Some of the physico-chemical and organoleptic characteristics do not conform to those described by Codex Alimentarirus and European Commission. Moreover, their labeling on the packaging has to conform to that of [4]. Indeed, the labeling should not mislead the consumers with regard to the composition of the product and its origin, and persuade them that this foodstuff possesses particular characteristics [5].

In developed countries, many studies have shown several cases of honey adulteration. In Sub Saharan Africa, and particularly in Burkina Faso studies have concentrated on melliferous plant species [6,7], and the impact of temperature on honey storage [8]. However in many developing countries well laid down mechanisms to control the quality of honey is absent. This makes it difficult for producers to meet export standards of the European Commission or Codex Alimentarius [9].

This study aims to draw consumers' attention to international standards as related to the importation and sale of honeys in Burkina Faso. The labeling will be verified 
according to the standards outlined in the [4] and the physico-chemical characteristics according to [2] and European Honey Commission [1].

\section{Material and Methods}

Imported honeys in super markets in Ouagadougou, Burkina Faso were sampled on 05 April 2013. According to the availability, three to five honey pots per sample of any type were bought. The interior temperature of the shelf where honeys were displayed was recorded with Kestrel 4000 version: 4.29 ALL. All the honey samples were analyzed at the laboratories of the Centre d'Etude Technique Apicole de Moselle, France according to the harmonized methods of the European Honey Commission [1]. The following characteristics of the honey samples were analyzed: coolness indicators as Hydroxymethyl-furfural (HMF) and diastasique activity (amylase); stability indicators as moisture, $\mathrm{pH}$, free acidity, fructose and glucose; botanical origin as electrical conductivity and the colour.

The information on the labeling was verified according to the Directive 2000/13/CE [10]. According to this directive, the information which necessarily have to appear in the case of honey are: the name of sale, the net quantity, the particular conditions of conservation and use, the company name and the address of manufacturer, the deadline for optimal use (DLUO), the geographical origin and the indicative price.

\section{Results}

Generally, the labeling of the imported honey jars was regular. Legal requirements were presented (Table 1). However the name and the address of producers were not mentioned as shown in the table.

Most of the honey samples (72.72\%) were mixed flower honeys with their geographical origin being from or outside the European Commission (Table 1). Two honey samples (18.18\%) were from Spain and one from Australia.

According to the Deadline for Optimal Use stated, one of the honey samples had expired (01/04/2013). Three will expire in 2013, six in 2014 and only one in 2015.

Two honeys ( $\mathrm{N}^{\circ} 9$ and 11) had the same name (miel d'oranger), but they didn't have the same composition and the same geographical origin. Four honey samples had the botanical origin as miel d'Acacia, d'oranger, d'oranger and romarin); two were honeydew honeys (miel de montagne, miel de forêt et de sapin); the others were flower honeys.

Table 2 summarized the results of the analysis of the honey samples in terms of their coolness, stability, color and botanical origins. All these characteristics are important to the product quality and therefore the consumers' health.

The Hydroxy-methyl-furfural (HMF) content varied from $29.9 \mathrm{mg} / \mathrm{kg}$ for sample $\mathrm{N}^{\circ} 1$ to $122.7 \mathrm{mg} / \mathrm{kg}$ for sample $\mathrm{N}^{\circ}$ 8. The HMF content of most of the honey samples (81.81\%) exceeded the Codex Alimentarius and European commission standard that were less or equal to $40 \mathrm{mg} / \mathrm{kg}$. Only two samples $\left(\mathrm{N}^{\circ} 1\right.$ and 11$)$ had their $\mathrm{HMF}$ value under $40 \mathrm{mg} / \mathrm{kg}$. For the amylase content, the values varied from 4 to 15 Schade unity $\left(\mathrm{N}^{\circ} 4\right.$ and $\left.\mathrm{N}^{\circ} 15\right)$. Forty-five and half per cent (45.5\%) had their values

Table 1. Presentation of honey samples according to the descriptions on the labeling.

\begin{tabular}{|c|c|c|c|c|c|}
\hline \multicolumn{6}{|c|}{ Presentation of different honey samples } \\
\hline $\mathbf{N}^{\circ}$ & Denomination & Geographical origin & Net weight (g) & DLUO & Price $(€)$ \\
\hline 1 & Miel de forêt et de sapin & Mixture of honeys from EC and non EC & 375 & 01/09/2013 & 5.27 \\
\hline 2 & Miel de montagne & Spain & 250 & $01 / 04 / 2013$ & 5.56 \\
\hline 3 & Miel crémeux & Mixture of honeys from EC and non EC & 250 & $01 / 01 / 2014$ & 5.27 \\
\hline 4 & Miel de fleurs & Mixture of honeys from EC and non EC & 375 & 01/07/2014 & 7.91 \\
\hline 5 & Miel de fleurs & Mixture of honeys from EC and non EC & 450 & 01/07/2014 & 5.37 \\
\hline 6 & Miel d'acacia & Mixture of Acacia honey from EC & 375 & $01 / 10 / 2013$ & 8 \\
\hline 7 & Tartimiel & Mixture of orange tree and Acacia from EC and non EC & 250 & $01 / 07 / 2014$ & 5 \\
\hline 8 & American green & From Australian & 500 & 03/2015 & 3.43 \\
\hline 9 & Miel d'oranger & Mixture of orange tree honeys from Spain and Mexico & 250 & $01 / 10 / 2014$ & 5.27 \\
\hline 10 & Miel de romarin & Mixture of rosemary honeys from Spain & 375 & 01/08/2013 & 7.94 \\
\hline 11 & Miel d'oranger & Mixture of honeys from EC and non EC & 250 & $30 / 10 / 2014$ & 4.88 \\
\hline
\end{tabular}

EC: European Community; DLUO: Deadline for optimal used. 
Table 2. Physicochemical characteristics of imported honey samples.

\begin{tabular}{|c|c|c|c|c|c|c|c|c|}
\hline \multirow{2}{*}{$\mathrm{N}^{\circ}$} & \multicolumn{2}{|c|}{ Product freshness } & \multicolumn{3}{|c|}{ Product stability } & \multirow{2}{*}{$\begin{array}{c}\text { Botanical origin } \\
\begin{array}{c}\text { Electrical conductivity } \\
(\mu \mathrm{S} / \mathrm{cm})\end{array}\end{array}$} & \multicolumn{2}{|c|}{ Colour } \\
\hline & $\begin{array}{c}\text { HMF } \\
(\mathrm{mg} / \mathrm{Kg})\end{array}$ & $\begin{array}{c}\text { Amylase } \\
\text { (Schade unity) }\end{array}$ & $\begin{array}{c}\text { Moisture } \\
(\mathrm{g} / 100 \mathrm{~g})\end{array}$ & $\mathbf{p H}$ & $\begin{array}{c}\text { Free acidity } \\
(\mathrm{mEq} / \mathrm{kg})\end{array}$ & & $\begin{array}{c}\text { Pfund } \\
\text { scale (mm) }\end{array}$ & $\begin{array}{l}\text { USDA colour } \\
\text { standards }\end{array}$ \\
\hline 1 & 38.5 & 15 & 17.5 & 4.84 & 15 & 993 & 150 & Dark amber \\
\hline 2 & 44.7 & 14 & 17.5 & 3.58 & 18.9 & 540 & 150 & Dark amber \\
\hline 3 & 50.5 & 11 & 18.4 & 4.06 & 11.1 & 393 & 66 & Light amber \\
\hline 4 & 89.9 & 4 & 17.8 & 4.09 & 11.9 & 284 & 58 & Light amber \\
\hline 5 & 62.8 & 8 & 17.8 & 4.06 & 9.2 & 243 & 58 & Light amber \\
\hline 6 & 46.4 & 7 & 17 & 4.37 & 6.1 & 125 & 22 & White \\
\hline 7 & 75.9 & 7 & 16.9 & 3.96 & 8.4 & 224 & 61 & Light amber \\
\hline 8 & 122.7 & 4 & 16.4 & 4.39 & 5.1 & 119 & 69 & Light amber \\
\hline 9 & 45.6 & 9 & 17.9 & 4.22 & 12.5 & 260 & 77 & Light amber \\
\hline 10 & 100.4 & 7 & 17.7 & 4.01 & 9.5 & 172 & 68 & Light amber \\
\hline 11 & 29.9 & 10 & 16.4 & 4.15 & 12.8 & 687 & 41 & Extra light amber \\
\hline
\end{tabular}

over the Codex Alimentarius and European Commission standard and 54.55\% had their values lower than 8 Schade unity.

For the stability, all of honey samples conformed to the standard of the Codex Alimentarius and that of the European Commission. The $\mathrm{pH}$ value varied from 3.58 to 4.84. Only one honey sample $\left(\mathrm{N}^{\circ} 1\right)$ had $\mathrm{pH}$ level being the same as that of the honeydew honeys. In terms of the free acidity, the value varied from 5.1 to $18 \mathrm{meq} / \mathrm{kg}$. All the values were lower than $50 \mathrm{meq} / \mathrm{kg}$.

The conductivity of honey samples showed that most of them (90.90\%) were flower honeys with conductivity lower than $0.8 \mathrm{mS} / \mathrm{cm}$. Only one sample $\left(\mathrm{N}^{\circ} 1\right)$ had conductivity more $0.8 \mathrm{mS} / \mathrm{cm}$.

According to US Department of Agriculture colour standards [11], the honey samples varied from dark amber $\left(\mathrm{N}^{\circ} 1\right.$, and 2$)$ to white $\left(\mathrm{N}^{\circ} 6\right)$. Many (63.63\%) were of light amber in colour.

\section{Discussion}

Despite the important efforts done in physico-chemical analyses, the detection and the quantification of honey adulterations continue to be a difficult problem [12]. Even with the adaptation of international standards, the detection and authentication of honeys have become a preoccupation of many. In terms of honey labeling, the results show that honey samples fulfilled the criteria of the European commission and Codex Alimentarius. Only one sample failed to meet the criteria. But according to [5] and [13], the DLUO does not mean that the honey cannot be consumer, but it means that the honey must not fermented. It however meets the legal quality criteria, par- ticularly the index of age as indicated by the HMF and Diastase Index.

The producer cannot be responsible for bad storage conditions of the distributor or in the consumers' houses. This is why it is necessary to indicate the particular conditions for good storage of honey.

For the physico-chemical analyses, the expired honey sample fulfilled a lot of criteria except the HMF value where it was slightly higher than $40 \mathrm{mg} / \mathrm{Kg}$.

The honey freshness is an important criterion for the consumers [14]. Indeed, the diastase index and the HMF content are quality factors and they give the age and the thermal past of the honey [15].

For the HMF content, a lot of honey samples did not meet the standard of the Codex Alimentarius and the European Commission. Indeed, at harvest, the comb honey does not have any HMF value, but time and the temperature accelerates its formation and according to [16], this value is multiplied by 1.10 times in six months and by 2.0 in one year when honeys were stored between $15^{\circ} \mathrm{C}$ and $20^{\circ} \mathrm{C}$. This explains this high HMF value of the sampled honeys because they were storage at $30^{\circ} \mathrm{C}$. Nevertheless, two samples despite their DLUO fulfilled this HMF criterion.

The results of the enzymes activities bring good information on the thermal treatment of the honeys studied. Its interpretation allows for the detection not only the freshness state of honey but also the optimal conditions of storage. Finally, when the history of the honey is not known, the analysis allows for the detection of the kind of degradation that it has been subjected [15].

For the diastasique index, a lot of honey samples studied were degraded. That can be explained by the storage 
temperature because according to $[3,16]$, the amylase content is sensitive to the temperature and these small values can be a proof of deterioration due to excessive heating.

One honey sample $\left(\mathrm{N}^{\circ} 1\right)$ is honeydew honey by its denomination and its physicochemical characteristics. Indeed, according to [17], honeydew honey is characterized by its very dark colour (dark amber), its high $\mathrm{pH}$ value (4.84) and its electrical conductivity $(0.9 \mathrm{mS} / \mathrm{cm})$. The others honey samples were of flower origin.

The honey colour is the physical property perceived immediately by the consumers [18]. Even if the colours were from the plant species foraged by honeybees, the temperature also influence it. The honey samples fulfilled the international norms.

Only two honey samples, one from honeydews honey $\left(\mathrm{N}^{\circ} 1\right)$ and the second from flowers $\left(\mathrm{N}^{\circ} 11\right)$ fulfill the Codex Alimentarius and the European commission norms. The sample $\mathrm{N}^{\circ} 8$ with $122.7 \mathrm{mg} / \mathrm{Kg}$ of HMF content and 4 Schade unity of diastase index and DLUO in 2015 is the most degraded honey. Probably it has been heated. The sample $\mathrm{N}^{\circ} 6,9$, and 11 would had less diastase index because they were from Acacia and Citrus or according to [19] the honey of such characteristics are naturally poor in diastase. The others samples $\mathrm{N}^{\circ} 4,6,7$, and 10 with high HMF level and low diastasique index have been degraded by the storage temperature near 30 ${ }^{\circ} \mathrm{C}$ because according to [8], the tropical temperature of storage increase the HMF and amylase content rapidly and that can reduce considerably the honeys' DLUO.

\section{Conclusion}

The results show that a lot of honey samples fulfill the labeling criterion. Also, lots of them have been degraded by storage temperature. Only two honey samples fulfill the Codex Alimentarius and European Commission norms. The temperature in tropical area is an important factor that limits the DLUO. Accordingly a storage condition, the DLUO between 6 months and one year is suggested for the honeys sold in tropical regions. That will allow for the preservation of their qualities. The invertase and sugars content and also pollen analysis have not been carried out during this study. These would allow the detection of sugar adulteration by the addition of saccharose syrup. Another important characteristic is the presence of antibiotics. This affects the honey quality and can pose enough danger to public health. Future studies will be concentrated on the above so as to constitute a database for improving the honey quality and to be able to monitor the characteristics of imported honeys in Burkina Faso.

\section{REFERENCES}

[1] S. Bogdanov, P. Martin and C. Lüllmann, "Harmonised
Methods of the European Honey Commission,” Apidologie, Extra Issue, 1997, pp. 1-59.

[2] Codex Alimentarius Commission, "Rapport de la 7e Session du Comité sur les Sucres,” Programme Mixte FAO/ OMS sur les Normes Alimentaires, 2001.

[3] N. Breadbear, "Bees and Their Role in Forest Livelihoods: A Guide to the Services Provided by Bees and the Sustainable Harvesting, Processing and Marketing of Their Products,” Non Wood Forest Products 19, Food and Agriculture Organization of the United Nations, Rome, 2009.

[4] Journal Officiel, “Décret n 2003-587 du 30 Juin 2003 Pris Pour l'Application de l'Art. L. 214 du Code de la Consommation en EC qui Concerne le Miel,” 2003. http://www.legifrance.gouv.fr/

[5] L. Lequet, "Du Nectar au Miel de Qualité: Contrôle Analytique du Miel et Conseils Pratiques à l'Intention de l'Apiculteur Amateur," Thèse de Doctorat Vétérinaire, Université Claude-Bernard Lyon I, France, 2010.

[6] I. Nombré, P. Schweitzer, M. Sawadogo, I. J. Boussim and J. Millogo-Rasolodimby, "Assessment of Melliferous Plant Potentialities in Burkina Faso," African Journal of Ecology, Vol. 47, No. 4, 2009, pp. 622-629. http://dx.doi.org/10.1111/j.1365-2028.2009.01034.x

[7] I. Nombré and P. Schweitzer, "Beekeeping in Burkina Faso: Inventory of Fixtures,” In: G. Bondurand and H. Bosch, Eds., Honey: Production, Consumption and Health Benefits, Series: Food and Beverage Consumption and Health, New York, 2012, pp. 165-182.

[8] I. Nombré, P. Schweitzer, I. J. Boussim and J. Millogo/ Rasolodimby, "Impacts of Storage Conditions on Physicochemical Characteristics of Honey Samples from Burkina Faso,” African Journal of Food Science, Vol. 4, No. 7, 2010, pp. 458-463.

[9] M. Mutsaers, H. Blitterswijk Van, L. Leven van't, J. Kerkvliet and J. Waerdt Van, "Produits de l'Apiculture: Propriétés, Transformation et Commercialisation,” Agrodok No. 42, Fondation Agromisa et CTA, Wageningen. 2005.

[10] E. Bruneau, “Comment Étiqueter son Miel?” Abeilles \& Cie, Vol. 108, No. 5, 2005, pp. 24-26.

[11] S. Bogdanov, "Physical Properties of Honey," In Book of honey, Chapter 4, Bee Product Science, 2010, pp. 1-9.

[12] B. Christophe, Y. Cordella and I. Moussa, "Pister les Fraudes dans les Miels. L'apport des Microscopies et de la Spectrométrie de Masse du Carbone 13," L'Actualité Chimique, No. 330, 2009, pp. 7-13.

[13] H. Dailly, "Concevoir son Étiquette, ce Qu'il Faut Savoir,”Abeilles \& Cie, Vol. 117, No. 2, 2007, pp. 26-29.

[14] I. Freytag, “Qualité des Miels du Commerce,” Abeilles \& Cie, Vol. 118, No. 3, 2007, pp. 21-24.

[15] E. Bruneau, "Voyage au Coeur du Miel,” ActuApi, Vol. 31, No. 3, 2005, pp. 1-8.

[16] F. Jeanne, “Le Miel: Éléments d'Analyse,” Bulletin Technique Apicole, Vol. 32, 2005, pp. 69-76.

[17] M. Diez, C. Andrés and A. Terrab, "Physicochemical Parameters and Pollen Analysis of Morocan Honeydew Honeys," International Journal of Food Science \& Tech- 
nology, Vol. 39, No. 2, 2004, pp. 167-176. http://dx.doi.org/10.1046/j.0950-5423.2003.00769.x

[18] L. M. Piana, L. Persano Oddo, A. Bentabol, E. Bruneau, S. Bogdanov and C. Guyot Declerck, "Sensory Analysis Applied to Honey: State of the Art,” Apidologie, Vol. 35, Suppl. 1, 2004, pp. 26-37. http://dx.doi.org/10.1051/apido:2004048

[19] H. Clément, E. Bruneau, J. M. Barbançon, P. Bonnaffé, R. Domérogo, G. Fert, Y. Le Conte, J. Ratia, C. Reeb and B. Vaissière, “Le Traité Rustica de l'Apiculture," Traité Rustica, Paris, 2002. 